\title{
The Introduction of Pneumatic Chemistry into France
}

IT is not hard to identify with some precision the path by which knowledge of the new discoveries on gases came to France from Britain or to point to the two men who were the humble agents in this historically significant transaction, who repeatedly insisted on the importance of the recent British experiments, and who transmitted the necessary books and information to the chemists of the Royal Academy of Sciences in Paris. The real instigator was that picaresque and largely neglected personage, João Jacinto de Magalhães (1722-1790), a Portuguese savant living in London, whose main channel of communication with French scientists was his patron and correspondent, Trudaine de Montigny (1733-1777), a worthy civil servant and membre honoraire of the Academy.

Magalhães-or Magellan, to use the form of his name he favored after leaving Portugal-had been born in Aveiro 


\section{PNEUMATIC CHEMISTRY}

of a family boasting descent from the famed navigator. ${ }^{1}$ Educated for the clergy, he early entered a congregation of Augustinian monks at Coimbra; he was thirty-one when he made the acquaintance of the French naval officer and astronomer, Gabriel de Bory (1720-1801), when the latter visited Portugal to observe a solar eclipse. Bory was received at the monastery of Coimbra and was struck by the scientific enthusiasm of the monks, especially of Magellan, who served as his guide and with whom he formed a lasting friendship. It was sometime after 1755 that Magellan, perhaps stimulated by this contact with the outside world, sought permission to leave the order and put the scientific backwater of Coimbra behind him. After a stay in Paris, interrupted by short trips to other European countries, he took up residence in London about 1764; here he lived, except for brief excursions to the Continent, until his death in 1790 .

This former cleric, described by an English contemporary as a tall and bony man, "plain in his dress, unaffectedly mild, and decent in his whole demeanour," soon attracted attention as an authority on those scientific instruments for which the English artisans had become famous. But he became even better known as a man of

${ }^{1}$ Magalhães seems to have rendered his name, or had it rendered by others, variously as Jean (or John) Hyacinthe de Magalhaens, or de Magellan. Few details are known of his life, but see John Nichols, Literary Anecdotes of the Eighteenth Century, VIII (1814), 48-51; the articles in Michaud, Biographie universelle; Didot-Hoefer, Nouvelle biographie générale; the Dictionary of National Biography; and the recent sketch by J. de Carvalho in his "Correspondência cientifica dirigida a João Jacinto de Magalhães," Revista da Faculdade de Ciências da Universidade de Coimbra, 20 (1951), 93-283; reprinted separately (Coimbra, 1952).

¿ Gentleman's Magazine, 60 (1790), 184. 
unbounded curiosity with a consuming desire to learn about-and to disseminate promptly and widely-the most recent scientific discoveries. Tireless as a letter writer, a versatile linguist with a wide European acquaintance, he kept alive an extensive and dogged correspondence. In consequence, though he published a few scientific works of modest value, ${ }^{3}$ he was chiefly thought of in his day as a scientific intelligencer, a purveyor of scientific gossip, indeed, something of a busybody, inspiring that mixture of cautious esteem and slight exasperation we detect in some references to him. ${ }^{4}$

${ }^{3}$ His first publication was his Description des octants et sextants Anglois .. . précédée d'un mémoire sur une nouvelle construction de ces instruments (London, 1775). A Description et usages des nouveaux baromètres pour mesurer la hauteur des montagnes et la profondeur des mines (London, 1779) and a Description of a Glass Apparatus, for Making Mineral Waters (London, 1777, and later editions) also dealt with scientific instruments. More important was the memoir in which he gave the first extended account of the theory of latent and specific heats: Essai sur la nouvelle théorie du feu élémentaire, et de la chaleur des corps (London, 1780), reprinted in Rozier's Observations sur la physique in May and June, 1781 (17, 375-386 and 411-422), and described by Douglas McKie and Niels H. de V. Heathcote, The Discovery of Specific and Latent Heats (London, 1935), pp. 40-45.

4 J. P. Brissot, who met him in London, wrote that Magellan "connaissait toutes les machines dont l'Angleterre fourmillait et, en s'occupant à les répandre par toute l'Europe, en se faisant le correspondant de tous les savants, il était parvenu . . . à une indépendance honorable" (Mémoires, ed. Cl. Perroud [Paris, 1911] I, 363 ). Brissot, who attempted in 1782-1784 to establish a center in London for the exchange of scientific information, found in Magellan a kindred spirit and remárked of him: "Il est un des premiers qui ait deviné combien la communication rapide \& générale des découvertes pouvait être utile aux Sciences, \& qui l'ait executé dans le centre le plus favorable pour le succès de cette correspondance, 


\section{PNEUMATIC CHEMISTRY}

A clubbable and inquisitive man, Magellan probably frequented Benjamin Franklin's circle of the Honest Whigs, with its strongly philosophic flavor and a scientific membership that included, besides Joseph Priestley, electrical experimenters like John Canton and William Watson; the economist, Richard Price; the merchant-naturalist, Peter Collinson; and the principal secretary of the Royal Society of London, Matthew Maty. But there is no definite evidence to link him with this group, beyond the nature of his interests, the range of his friendships, and a casual reference to him in an early letter of Franklin to Priestley (May 4, 1772). ${ }^{5}$ Franklin, who judged men well, seems to have discerned the merit and the utility of this odd personage, for he promoted Magellan's interests in various ways and chose on occasion to communicate through him with his scientific friends abroad. Priestley, who probably met him through Franklin or at the Honest Whigs, also found Magellan useful, as we shall see, but in addition genuinely liked him, enjoyed his conversation and worldly knowledge, and spoke of him as "very friendly, especially in every thing that related to my philosophical pursuits." ${ }^{6}$ Not everyone, however, trusted his discretion. James Watt, for example, described him to

à Londres même" (Journal du Licée de Londres, I [1784] 194, note 1 ).

${ }^{5}$ A. H. Smyth, ed., Writings of Benjamin Franklin, V, 394-396.

${ }^{6}$ Memoirs of the Rev. Dr. Joseph Priestley (London, 1809), p. 66. Priestley recalls the pleasant evenings he spent with Magellan during the famous visit to Paris in $\mathbf{1 7 7 4}$ in the company of Lord Shelburne and notes the fact that Magellan accompanied him back to London. But he nowhere indicates when his association with Magellan began. 


\section{LAVOISIER-THE CRUCIAL YEAR}

Joseph Black as "well-meaning, but no philosopher," and warned Black that "he has an extensive correspondence and may circulate erroneous doctrines to the prejudice of your honor." " But even Watt used his services and through him sent drawings and specifications to the French engineers who were to erect his improved steam engine in France.

At all events, Magellan's friendly assiduity and the high patronage of Priestley and Franklin made him a Fellow of the Royal Society in 1774. Ten years later, doubtless at Franklin's prompting, the American Philosophical Society elected him a Fellow. He responded by sending shipments of books and instruments and by endowing the Magellanic Prize, which has been awarded since his time to "the author of the best Discovery, or most useful Improvement relating to Navigation or Natural Philosophy." 8

Despite these honors and credentials Magellan's chief distinction may well turn out to be the part he played in 1771-1772, at a turning point in the history of chemistry, as a trait d'union between the largely insulated scientific

${ }^{7}$ A reference to Magellan's intention of attributing the discovery of latent and specific heats, not to Black, but to the Swedish scientist, Johan Carl Wilcke. See James Patrick Muirhead, The Origin and Progress of the Mechanical Inventions of James Watt (London, 1854), II, 117-118. Richard Kirwan in 1788 accused Magellan of "plundering my Mineralogy" for his edition of Cronstedt and expressed regret to Sir Joseph Banks that he had not taken Banks's advice to beware of Magellan (Warren R. Dawson, ed., The Banks Letters [London, 1958], 493).

${ }^{8}$ Early Proceedings of the American Philosophical Society, 17441838 (Philadelphia, 1884), pp. 121-122 and 135. The "Certificate Book" of the Royal Society shows that on January 20, 1774, Magellan's certificate was signed by Joseph Priestley and Benjamin Franklin. I owe this information to Professor Robert Schofield, of the Case Institute of Technology. 


\section{PNEUMATIC CHEMISTRY}

worlds of Britain and France. Yet this aspect of his career has not, so far as I know, been hitherto brought to light.

The earliest trace of Magellan's epistolary activity is a letter to him from the French astronomer, Charles Messier, published in the Philosophical Transactions in 1769. If he wrote in these early years to other scientists in France, like his friend Bory, we have no evidence of the fact. But the letters that have survived show that by 1770 Magellan was engaged in a rather special pursuit, acting as unpaid confidential agent of the French Government and regularly informing Trudaine de Montigny, who was director of the French Government's Bureau de commerce, of important British inventions and technical improvements. ${ }^{9}$ This French program of industrial espionage, for it deserves this rather strong term, was no recent innovation; it had been carried on with great success by Trudaine de Montigny's father and predecessor in office, the muchadmired Daniel Trudaine (1703-1769), who over the years had made regular use of technically trained agents to ferret out the secrets of foreign, and especially British, industrial superiority.$^{10}$ At first Magellan's role was no dif-

${ }^{9}$ Arthur Birembaut, "Sur les lettres du physicien Magellan conservées aux Archives Nationales," Revue d'histoire des sciences, 9 (1956), 150-161.

${ }^{10} \mathrm{~A}$ brief account of Daniel Trudaine's program of industrial espionage is given in my "French Antecedents of the Chemical Revolution," loc. cit., pp. 94-98. A careful study of the Trudaines, father and son, is badly needed, but see Suzanne Delorme, "Une famille de grands Commis de l'Etat, amis des Sciences au XVIII siècle: Les Trudaine," Revue d'histoire des sciences, 3 (1950), 101-109. Capitaine Andrieux's Trudaine, sa vie, son oeuvre, ses idées (ClermontFerrand, 1922) is of little value, but there is useful material in Ernest Chouillier, "Les Trudaines," Revue de Champagne et de Brie, 14 (1883), 19-20 and 131-138. 
ferent from that of such other agents as Gabriel Jars, J. P. F. Guillot Duhamel, John Holker, and Nicolas Desmarest, for we find him sending the younger Trudaine packages of books and pamphlets describing new inventions and even, on one occasion, attempting to smuggle out of England a new kind of loom the British were reluctant to export.

Magellan's interests were, however, primarily scientific, and we soon find him reporting on the new instruments of John Bird (1709-1776), Jesse Ramsden (1735-1800), and other skilled English artisans and sending samples of British flint glass so that French astronomers could equip themselves with achromatic refractors like those which John Dollond had successfully made some years before. This could not have displeased Trudaine de Montigny, who, though a far less able administrator than his father, was more scientifically inclined. Succeeding to his father's place in the Academy of Sciences in 1764, the younger Trudaine displayed a keener interest in its affairs than had his father; was on terms of intimacy with a number of the scientists; and later became-as is well known-a friend, patron, disciple, and (for a brief time and to a modest extent) the collaborator of Lavoisier. ${ }^{11}$ It was at Trudaine's instigation and as a reward for his services to the Bureau de commerce that Magellan on September 4, 1771, was made a corresponding member of the Academy, assigned to keep in touch with his old friend Bory. ${ }^{12}$ Yet even before this formal association with the Academy, Magellan was writing with some regularity to its distin-

${ }^{11}$ Ralph E. Oesper, "Priestley, Lavoisier, and Trudaine de Montigny," Journal of Chemical Education, 13 (1936), 403-412.

12 Birembaut, loc. cit., p. 156. 
guished senior chemist, P. J. Macquer. Some of this correspondence, or at least of Magellan's part of it, has survived to tell a surprising story: that it was, in a manner of speaking, as a by-product of the French program of industrial and technical espionage, carried on by the two Trudaines, that a knowledge of British progress in pneumatic chemistry was at last brought to the attention of the French scientists.

\section{The Introduction of Pneumatic Chemistry into France}

On May 4, 1771, Magellan dispatched to Macquer from London the first letter that has been preserved from this correspondence. In this letter he recalls his promise, made during a visit to Paris the summer before, to send Macquer specimens of "gomme élastique," by which he means, of course, crude rubber. ${ }^{13}$ For some years Macquer had been investigating the properties of this novel material, this barbarously named caoutchouc, which La Condamine had first brought to the attention of the scientific world; ${ }^{14}$ in fact, Macquer had already published, in two memoirs, the first serious studies of rubber in chemical literature. ${ }^{15}$

13 Macquer correspondence, Bibliothèque Nationale, Paris, MS Fr. 12306, no. 11.

14 "Mémoire sur une résine élastique, nouvellement découverte à Cayenne par M. Fresneau," Mém. Acad. roy. sci. for 1751 (1755), pp. 319-333. La Condamine had sent samples of rubber from Peru as early as 1736, soon after his arrival at Quito on the famous geodetic expedition.

${ }^{15}$ For Macquer's research on rubber see Coleby, op. cit., pp. 116117. An unpublished letter of Bertin to Macquer, dated Versailles, April 21, 1768, shows that the government, or at least this enlightened minister, took more than a casual interest in Macquer's research. Bertin thanks Macquer for sending him a copy of the memoir 
Magellan's letter goes on to explain that he had long since asked a friend in Portugal to obtain samples for him but that these had only recently been received and would be forwarded. Then, changing the subject, he remarks that Macquer must surely know that an English translation of his famous Dictionnaire de chymie had recently been announced in London. According to the prospectus, which Magellan has seen, the English edition is to be accompanied by notes of the translator.

This was news to Macquer, who apparently wrote asking Magellan to send more information; for when the latter replied on August 20, he announced that he had already purchased from the bookseller twenty-five gatherings of the forthcoming book and would pack them, specially marked, in a box destined for Trudaine de Montigny, so that Trudaine's secretary could transmit them to the chemist. ${ }^{16} \mathrm{He}$ had not been able to identify the translator, Magellan wrote, except that he is "un gentil-home [sic] de Birmingham \& qu'il fait travailler des mines de fer pour son compte"; though primarily a metallurgist, as some of his notes indicate, he is not ignorant of chemistry. Magellan then quoted a significant passage from the prospectus. Such a project as the Dictionnaire, so ran the comments of the translator, was perhaps too vast for one man to carry out, and the author has left out many articles which should have been included. The chief omissions are due

on "la résine élastique," and continues: "Je me felicite vrayment de vous avoir engagé à travailler a un objet dont on peut tirer avantage, d'après la bonne découverte que vous avés fait. Mandés moy je vous prie si M. de Vaucanson en a connoissance" (Bib. Nat., MS Fr. 12305, no. 113).

${ }^{16}$ Bib. Nat., MS Fr. 12306, no. 13. 


\section{PNEUMATIC CHEMISTRY}

to "the Author not having been acquainted with some very late discoveries, specialy [sic] those important ones Concerning fixable air, made by Doctor Black, Professor of Chemistry in the University of Edinburgh, by Doct. Macbride (of Dublin), and by the Honorable Mr. Cavendish." 17 These omissions he proposes to remedy by adding notes of his own.

Of Macquer and his Dictionnaire, which indeed suffers from these significant omissions, little need be said, for the man and the book are, or should be, familiar to all students of the history of chemistry. Though only an associe chimiste of the Academy of Sciences at the age of fifty-three, Macquer unquestionably ranked as France's outstanding chemist. The author of some twenty memoirs and of one of the best textbooks to appear during the century, he taught chemistry in public lectures at the Jardin du Roi. In 1766 he succeeded to two technical governmental posts: that of Inspector General of the dye industry and that of chief scientist of the porcelain factory at Sèvres. The same year he published anonymously in two volumes his Dictionnaire de chymie, a remarkably successful work, which he hastened to acknowledge in later editions and which was translated into English, Ger-

${ }^{17}$ Ibid., no. 13. An almost identical comment appears in the preface to the translation. See A Dictionary of Chemistry (London, 1777), I, pp. iii and iv. For convenience I have worked from this second English printing, but I was able to compare it with the first English edition of 1771 in the Library of the Institute of the History of Medicine of the Johns Hopkins University. An important note concerning factitious airs discusses the work of Hales, Cotes, Black, and Cavendish ( $I, 33$, note b). Macquer's article on quicklime is translated intact; but in a long note (I, 602, note 1 ), Black's theory of causticity is carefully explained. 
man, Italian, and Danish. No single work, I believe, can give the modern student a better picture of the state of Continental chemistry before Lavoisier than this first edition of Macquer's dictionary.

Less eminent, though destined to be a figure of note, was the man who undertook the first English translation of Macquer's two volumes and whose name Magellan did not at first know. James Keir (1735-1820), the "gentleman of Birmingham," had studied medicine at Edinburgh in company with the famous Erasmus Darwin. ${ }^{18}$ Unlike his lifelong friend, he did not enter medical practice but served instead with the army in the West Indies until after the close of the Seven Years' War. On his return to England he settled at Birmingham about 1770 , probably at the urging of Darwin and Matthew Boulton, and devoted himself to the study of chemistry. Perhaps, as Magellan suggests, he launched his career of industrial chemist as a mineowner and metallurgist. Later, however, we find him the coproprietor of a glassworks at nearby Stourbridge; and in 1778 he abandoned this venture to take over, for a time, the direction of Boulton's Soho works. In 1780, in partnership with an old army friend, Alexander Blair, he founded a chemical factory at Tipton to exploit a process he had developed for the manufacture of alkali. Never far removed from Birmingham, he was one of the

${ }^{18}$ Mrs. Amelia Moilliet's privately printed Sketch of the Life of J. Keir, F.R.S. (London, 1859) is the chief biographical source; the main facts are summarized in the Dictionary of National Biography. Keir's relations to Darwin and others of the Lunar Society are set forth in Hesketh Pearson, Doctor Darwin (London and Toronto, 1930). His position as a pioneer industrial chemist is emphasized in Archibald and Nan L. Clow, The Chemical Revolution (London, 1952), pp. 95-100, 133, and passim. 
honored members, and indeed one of the founders, of the Lunar Society, the extraordinary group of midland worthies that included Darwin, Boulton, James Watt, Josiah Wedgwood, and, after 1780, Joseph Priestley. Keir's chemical investigations were always industrially oriented: he worked on new alloys with Boulton; he studied the crystallization observed in glass and experimented with glazes for Wedgwood's pottery; but he also kept alive a keen interest in pneumatic chemistry, remained a staunch phlogistonist, as Humphry Davy later testified, and discussed problems with Priestley and performed difficult analyses for him. A number of Keir's papers were published in the Philosophical Transactions. He became a Fellow of the Royal Society in 1785.

It was perhaps to refurbish the chemistry he had learned at Edinburgh as a student of Andrew Plummer that Keir undertook, soon after resigning his army commission, to render Macquer's Dictionnaire into English. The task, as we have seen, was completed by 1771. Early in October the last two gatherings had come off the press, and the alert Magellan sent them on to Macquer in Paris. ${ }^{19}$ Later in the same month our intelligencer raised once again the problem of "fixed air," for he had recently had, he wrote, a conversation with a friend who had supplied information which perhaps “n'est pas connu en France de tous les curieux." ${ }^{20}$ This information, chiefly the names of works written on this absorbing topic, he forthwith reported to Macquer. Seemingly unaware that Meyer's work had been translated into French, he refers in this let-

${ }^{19}$ Letter dated London, October 5, 1771 (Bib. Nat., MS Fr. 12306, no. 15).

${ }^{20}$ Letter dated October 25, 1771 (ibid., no. 16). 
ter to the German apothecary's treatise on lime, with its theory of acidum pingue, remarking that "le Dr. Black d'Edinburgh tache d'expliquer les memes phenomenes par son systeme de l'air fixe ou fixable." A certain Mr. Rousseau of Munich, he continues, has made quicklime with the solar heat of a burning glass and finds that it will not yield the lapis infernalis. This experiment, "bien digne d'etre repétée et bien examinée par un homme Comme Vous," seems to prove that ordinary fire, in driving out from calcareous stones some particles of water and fixed air, deposits some of its particles, or a certain phlogistic and inflammable principle. ${ }^{21}$

Magellan then informed Macquer about two other German works dealing with "fixed air": Nicolas Jacquin's Examen chemicum ${ }^{22}$ and a pamphlet by a certain " $\mathrm{M}^{\mathrm{r}}$. Crantz," entitled Examinis chemici doctrinae Meyerianae . . rectificatio ${ }^{23}$ which had appeared in 1770 . And Magellan added:

${ }^{21}$ If these results were actually printed, I have not identfied the work in which they appear. This chemist was probably Georg Ludwig Claudius Rousseau (1724-1794), who is accorded an article by Poggendorff, but is not mentioned by Kopp or Hoefer. There are several references to Rousseau in J. F. Gmelin, Geschichte der Chemie (Göttingen, 1797-1799). See especially II, 713 and III, 475. Rousseau was an apothecary of Ingolstadt (not Munich) and professor at that Bavarian university.

${ }^{22}$ Nicolaus Joseph von Jacquin, Examen chemicum doctrinae Meyerianae de acido pingui et Blackianae de aere fixo, respectu calcis (Vienna, 1769). This book of N. J. Jacquin (1727-1817), a professor of botany and chemistry at Vienna, was translated into German in 1770; its first effect was to launch in Germany and Holland a controversy on the relative merits of the ideas of Blackwhich Jacquin defended-and those of Meyer. For Jacquin see Hoefer, op. cit., II, 335-336, and John Ferguson, Bibliotheca chemica (Glasgow, 1906), I, 432.

${ }^{23}$ Heinrich Johann Nepomuk von Crantz (1722-1799); the full 


\section{PNEUMATIC CHEMISTRY}

Je puis vous envoyer Ces deux brochures d'ici, en cas que Vous ne les ayez pas à Paris. Je souhaite que vous examinies bien cette matierre, \& ce qu'on a ecrit sur elle. Vous saves que Macbride en a traité \& dans les Transact. Philosoph. dernierement (il y a environ 3 ou 4 annees) il y a des bonnes experiences sur celà par $\mathbf{M}^{\mathrm{r}}$. Cavandish [sic] \& une [sic] Memoire de $\mathrm{M}^{\mathrm{r}}$. Lane, qui a fait des eaux calybeates par le moien de l'air fixe. ${ }^{24}$

Here we find assembled for Macquer's enlightenment the names and works of several of those men Lavoisier was later to discuss with such care in the historical section of his Opuscules physiques et chymiques (1774)..$^{25}$ But it is likely that Lavoisier at this time was just as ignorant of them as Macquer probably was. Macquer, for his part, seems to have paid little attention to Magel-

title of the work cited is Examinis chemici doctrinae Meyerianae de acido pingui et Blackianae de aëre fixo respectu calcis rectificatio (Leipzig, 1770). It is a defense of Meyer. For Crantz see the Allgemeine Deutsche Biographie. He is not mentioned in Poggendorff.

${ }^{24}$ Lane, a London apothecary, whom Priestley was to cite with approval, published a paper describing how iron could be dissolved by water impregnated with "fixed air." See Philosophical Transactions, 59 (1769), 216-227.

${ }^{25}$ Oeuvres de Lavoisier, I, 480-498. Among the works stimulated by the controversy of Meyer and Jacquin we may cite Johann Jacob Well's Rechtfertigung der Black'schen Lehre von der fixirten Luft (Vienna, 1771), Christian Ehrenfried Weigel's Observationes chemicae et mineralogicae (Göttingen, 1771), J. R. Spielmann's Examen acidi pinguis (Strasbourg, 1769). Wilhelm Bucholz' Chemische Versuche über das Meyerische Acidum Pingue (Weimer, 1771) was reviewed in the Journal encyclopédique (August 15, 1772, pp. 72 77). I doubt whether Macquer or Lavoisier was familiar with any of these works. In his Opuscules Lavoisier mentions Weigel's work but remarks, "Il ne m'a pas encore été possible de me procurer cet ouvrage" (Oeuvres, I, 555). 
lan's revelations; it was necessary to renew the attack at a later date.

\section{Magellan, Joseph Priestley, and the French Chemists}

One name is notably absent from the list of authors Magellan transmitted to Macquer on October 25, 1771the name of Joseph Priestley. This, of course, is understandable. At this time Priestley had not gone far with his experiments on gases and had yet to publish any of his results. ${ }^{26}$ It was not until March, 1772, that Priestley, at a series of meetings of the Royal Society, first made public the experiments which were to form the major part of his "Observations on Different Kinds of Air." ${ }^{27}$ This important classic, it should bear repeating, was not published until late in 1772, after Lavoisier had carried out his first experiments on combustion.

But did Magellan know Priestley as early as 1771? Could it have been Priestley who first told Magellan of Keir's translation and of the criticism leveled against Macquer's book? Was Priestley, perhaps, "the friend" who told Magellan about the writings of Meyer, Jacquin,

${ }^{26} \mathrm{~W}$. Cameron Walker's earlier paper ("The Beginnings of the Scientific Career of Joseph Priestley," Isis, 21 [1934], 81-97) has been largely superseded by Robert E. Schofield's "Scientific Background of Joseph Priestley," Annals of Science, 13, no. 3 (1957; published April, 1959), 148-163. Priestley's interest in gases began before he settled at Leeds in September, 1767, and found his plentiful supply of "fixed air" from the nearby public brewery. Between the fall of 1767 and the end of 1768 he was occupied with the production of artificial Pyrmont water. His more important discoveries were made in the course of 1771-1772.

${ }^{27}$ See my "Joseph Priestley's First Papers on Gases," loc. cit., pp. 1-7. 


\section{PNEUMATIC CHEMISTRY}

and Crantz? Likely as this seemed to me, there appeared at first to be no positive evidence that the two men were acquainted at this early date. A suggestive clue, however, was supplied by Priestley's History of Vision, Light, and Colours published in 1772. Appended to this book is a list of those works "of which Dr. Priestley is already possessed, or to which he has access, for compiling The History of Experimental Philosophy." ${ }^{28}$ A number of chemical writings are included, and among these one finds listed the French translation of Meyer and, rather surprisingly, the pamphlets of Jacquin and Crantz. Exceedingly rare today, the last two works could not have been common even then. Only a man with Priestley's special interests would have been likely to seek them out: he is the most promising candidate for the role of Magellan's "friend." But were these men acquainted, as we know them to have been a year later? The answer is supplied by the manuscript Journal Book of the Royal Society, where it is recorded that on March 14, 1771, Magellan attended a meeting of the Society as Priestley's guest. There is supporting testimony from Priestley himself. In a letter to the Dutch scientist, Ingenhousz, written ten years later, Priestley recalled that when he was making his experiments on the behavior of plants in vitiated airexperiments carried out in 1771 and 1772-he "wrote to my friends about them, particularly Mr. Magellan, and desired him to communicate my observations to you, as well as to others." ${ }^{29}$ I think it highly probable, therefore,

${ }^{28}$ Joseph Priestley, The History and Present State of Discoveries Relating to Vision, Light, and Colours (London, 1772). The list of books is not paginated.

${ }^{29}$ The quotation from this letter of November 21,1781 , and the 
that the first information the French chemists received about the state of pneumatic chemistry abroad can be traced in the first instance to Joseph Priestley.

It was Magellan, at all events, who informed the French scientific world, in the spring of 1772 , about the important discoveries Priestley had reported during the month of March at meetings of the Royal Society. This he apparently did, if we accept the evidence of the letter to Ingenhousz, with Priestley's approval, if not at his urging.

Priestley, to be sure, was already known in France for his History and Present State of Electricity, which had appeared in a French translation in $1771{ }^{30}$ Here, in a chapter on the conduction of electricity in "mephitic air," his name for carbon dioxide, Priestley mentions in passing that he had carried out experiments which convinced him that mephitic air was a fluid quite different from common air. This brief reference to his chemical work on gases, though the first he allowed to appear in print, could hardly have attracted the attention of French chemists. The information that he had been seriously investigating fixed air and other elastic fluids seems to have been first imparted by letters that Magellan wrote to Macquer in March, 1772.

entry in the manuscript "Journal Book of the Royal Society," vol. XVII (1771-1774), 45, were communicated to me by Professor Schofield, who is preparing a detailed study of Priestley.

${ }^{30}$ First published in 1767, and again in 1770, it had been translated into French by a disciple of the Abbé Nollet, with the addition of anti-Franklinist footnotes, as Histoire de l'électricité, traduite de l'Anglois de Joseph Priestley, avec des notes critiques (3 vols.; Paris, $1771)$. For the passage on mephitic air see this translation, especially III, 212-213. There is no reference to this passage in the review that appeared in the December, 1771, issue of Rozier's journal (Introduction aux observations, I, 389-394). 
The first we have is dated March 20, 1772; from it I cite the following important paragraph:

On Continua hier à Lire l'excellent Memoire sur l'air fixe \& le Mephitique, par Mr. Priestley, dans La Soce Royale \& on y a lu aussi la Communication d'un Medecin ou Chirurgien qui Cura d'une terrible fievre putride un malade en Lui appliquant par L'anus l'air fixe, qui se degageoit de la mixture de l'acide vitriolique avec le chalk ou pierre à Chaux moienant un tube qui étoit adapté à un Verre oû ledite mixture [sic] ou solution se faisoit. ${ }^{31}$

It is clearly implied that Magellan had previously reported to Macquer the earlier readings of Priestley's memoir to the Royal Society on March 5 and 12, but no such letter appears to have survived. Echoes of its contents, however, have come down to us. At the session of the Academy of Sciences held on April 1, 1772, Macquer read a letter of Magellan containing two of Priestley's observations: on the restoration of vitiated air by the gaseous exchange of plants and on the curative power of "fixed air" taken rectally. ${ }^{32}$ This letter was evidently passed on to the Abbé Rozier, who published a short notice of Priestley's discoveries in the April issue of his journal, the Observations sur la physique. Since this notice appeared under the heading "Nouvelles littéraries," it was not reproduced in the quarto reprint of 1777 and has only recently been brought to light by Douglas McKie in a careful study of the rare duodecimo edition of the $\mathrm{Ob}$ -

31 Bib. Nat., MS Fr. 12306, no. 18. The enterprising surgeon was Mr. William Hey, a friend whose work Priestley was to cite in his first published work on gases.

32 Procès-verbaux, 91 (1772), under date of April 1, 1772. 
servations. It is worth reproducing here as the first significant printed reference in France to Priestley's work on air:

Monsieur Priestly, connu par une histoire de l'électricité, dont nous avons rendu compte, dans le Volume de Décembre 1771, page 36, a lu à la Société Royale de Londres, un Mémoire intéressant, dont nous nous empressons de faire connoitre le sujet; il est intitulé: Recherches sur la nature de l'air b des parties qui le composent. Cet ouvrage est fondé sur un grand nombre d'expériences curieuses, \& M. Priestly y développe comment la nature supplée à cette prodigieuse quantité d'air consumé ou détruit par le feu \& par la flamme, \& il prouve par des expériences, que la végétation des plantes contribue à le remplacer \& à lui faire reprendre ses qualités; que l'air vicié $\&$ infecté par les vapeurs qui s'exhalent des corps tendans à la corruption \& dêja corrumpus, peut être renouvellé \& réparé par l'air fixe qui s'échappe d'un corps en fermentation.

On a donné à un malade un lavement d'air fixe, produit par une combinaison d'acide vitriolique \& de terre calcaire, \& ce remede singulier l'a heureusement délivré d'une fievre maligne \& putride, qui avoit résisté à tous les antiseptiques connus. Ce remede a été hasardé par un Chirurgien de la petite ville de Léeds. ${ }^{33}$

From the attention paid to Priestley's work on plants, which is not mentioned in the earliest surviving letter, it is clear that these important observations were reported in an earlier letter of Magellan missing from the correspondence, perhaps because Rozier, who based his account on it, never returned it.

${ }^{33}$ McKie, "The 'Observations' of the Abbé François Rozier," loc. cit., pp. 85-86. Professor McKie writes: "It will be seen that there was reliable detailed news of [Priestley's work on air] in Paris in April 1772, a month after it was read in London." He appears to be unaware of Magellan's role. 
A curious fact may be mentioned in passing: Lavoisier was present at the meeting where the letter concerning Priestley's work was read but does not seem to have been particularly struck by what he heard. Surviving among Lavoisier's papers are minutes in his hand, a so-called plumitif, which he took down for his own purposes during the meetings he attended during most of 1772 . This document differs at numerous points from the official minutes of the Secretary, chiefly by emphasizing matters which attracted Lavoisier especially. Under the date of April 1 he has nothing to say about the news of Priestley's work. The subject seems not to have interested him.

Nevertheless, it was not these inadequate reports on Priestley's great discoveries, but Priestley's first publication on gases, his Directions for Impregnating Water with Fixed Air, a portion of his research published separately in June, 1772, which first attracted real attention in France. $^{34}$ Somewhat surprisingly, it took this pamphlet on making artificial Seltzer water, or Pyrmont water, as the English called it-to our modern eyes a rather trivial affair and much less significant than the work of Black or even MacBride-to awaken French scientists, after their long slumber, to the possibilities of pneumatic chemistry. ${ }^{35}$

${ }^{34}$ Professor McKie seems to exaggerate when he writes that there was reliable and detailed news in Paris of Priestley's work a month after it was read in London. And I do not believe that it was these reports that led Lavoisier to include Priestley's name in the list of pneumatic chemists given in his famous memorandum of February, 1773, where, incidentally, he does not mention "Priestley's experiments on air," but merely lists his name.

${ }^{35}$ Joseph Priestley, LL.D. F.R.S., Directions for Impregnating Water with Fixed Air; In order to communicate to it the peculiar Spirit and Virtues of Pyrmont Water, and other Mineral Waters of a similar Nature (London: Printed for J. Johnson, No. 72, in St. Paul's Church-Yard, 1772). A facsimile of this pamphlet was printed 
The presumed medical value of this little pamphlet chiefly accounts for the excitement it aroused and the surprising attention bestowed upon it. In twenty-two pages Priestley describes a simple method of saturating water with Black's "fixed air," generated by the action of dilute sulphuric acid on chalk, and advocates the use of the impregnated water to cure scurvy, putrid fevers, and such maladies as diseased lungs, ulcerous sore throat, and even cancers. In the author's opinion, he was only making more accessible and easier to administer the new therapeutic substance, "fixed air," whose virtues had been demonstrated by Dr. MacBride, Sir John Pringle, Dr. Brownrigg ${ }^{36}$ and others. Probably it was the supposed efficacy of "fixed air" in the cure of scurvy, a pressing medical problem of immediate importance to maritime nations, which particularly commended Priestley's book to the Lord Commissioners of the Admiralty, to his friend Benjamin Franklin, always on the lookout for discoveries of practical import, and to French officials like Trudaine de Montigny, when they came to hear of it. Yet for our purposes what is important is that it seems to have been this modest book which at last focused attention in France on the neglected subject of Black's "fixed air."

It was Magellan, of course, who made Priestley's little

in Washington, D.C., in 1945 by the American Bottlers of Carbonated Beverages.

${ }^{36}$ For William Brownrigg, who reported that Pyrmont and similar mineral waters owe their acidulous taste to the presence of fixed air, see J. Russell-Wood, "A Biographical Note on William Brownrigg, M.D., F.R.S. (1711-1800)," Annals of Science, 6 (1949), 186196, and the same author's "The Scientific Work of William Brownrigg," loc. cit., 6 (1949), 436-447, and 7 (1951), 77-94 and 199206. 


\section{PNEUMATIC CHEMISTRY}

book known in Paris. On July 5 he sent to an unidentified correspondent a summary of recent work on the presumed curative power of "fixed air"; in this account he referred briefly to the work of Pringle, MacBride, Brownrigg, Lane, and Joseph Black and then presented an extended summary in his awkward French of Priestley's method of making soda water, with some slight modifications based on his own experiments. ${ }^{37}$ Two days later he wrote to Trudaine de Montigny, enclosing a copy of this correspondence, with the information that he had dispatched copies of Priestley's pamphlet by the last post. Magellan suggested that the Intendant of Finance might have his summary printed, after the French had been corrected, as a broadside to be widely distributed. ${ }^{38}$

It was at this point-a month before he wrote his August memorandum - that Lavoisier entered the picture, though not as significantly as one might have expected. Trudaine, who was then at his château at Montigny, wrote Lavoisier on July 14,1772, the following interesting letter, which is worth reproducing in full. With it he enclosed Magellan's communication of July 7, as well as a copy of the Priestley pamphlet.

\section{De Lavoisier fermier general}

A Montigny ce 14 Juillet 1772 J'ay l'honneur de vous envoyer, Monsieur, une lettre que je recois de M. Magallhaens Anglois catholique correspondant

${ }^{37}$ Oeuvres de Lavoisier-Correspondance recueillie et annotée par René Fric (Fascicule II, 1770-1775), (Paris, 1957), pp. 356366. M. Fric believes the unknown recipient of this document to have been Trudaine de Montigny. But the original letter was probably written to Rozier, with a copy sent to Trudaine.

${ }^{38}$ Ibid., pp. 366-367. 
de l'academie, au sujet d'une decouverte tres importante Sur l'air fixe. jy joins la petite brochure de M. Priestley qui est parfaitement bien faite a ce qu'il m'a paru. jimagine que vous entendez bien l'anglois. vous feriez une très bonne oeuvre très utile de faire publier cet ouvrage traduit avec les notes de M. Magallhaens. je vous prie aussi de vouloir bien repeter ces experiences, et d'ajouter vos propres observations. je vais repetter moi même ces experiences. en consequence, je vous prie de me renvoyer ma petite brochure aussitôt que vous l'aurez traduite ou fait traduire ce qui ne peut être long. le merite de ces nouvelles decouvertes etant la promptitude j'espere que vous ne tarderez pas a faire paroistre ce petit ouvrage. il n'y aura pas de mal a en prendre un nombre d'exemplaires pour faire distribuer gratis, principalement aux medecins. dans le desir de donner satisfaction à $M$. Magallhaens jay cru ne pouvoir mieux m'adresser qu'a vous je Scais votre exactitude Sur les details de Phisique et de Chimie et je Scais que c'est vous obliger que de vous mettre a portée de faire une chose utile. je travaille actuellement a devenir votre confrere chimiste. j’ay un laboratoire dont je ne Sors pas depuis trois jours qu'il est fini. Si je Suivois mon gout je m'y livrerois davantage. mais vous qui êtes jeune et qui avez du tems a vous, je vous exhorte a l'employer aussi utilement. vous connoissez depuis longtems, Monsieur, mon estime pour vos talens, et pour votre personne, et les Sentimens avec lesquels j’ay l'honneur d'être bien Sincerement, je vous assure, Monsieur, Votre très humble et très obeïssant serviteur.

Trudaine ${ }^{39}$

There is no evidence that Lavoisier followed Trudaine's exhortation and repeated-at least at this time-Priestley's simple experiments on soda water, though he was sufficiently interested to read Magellan's letter to the Academy

${ }^{39}$ Ibid., pp. 368-369. 


\section{PNEUMATIC CHEMISTRY}

at its meeting of July $18 .{ }^{40} \mathrm{He}$ could not very well have responded to Trudaine's suggestion that he translate Priestley's pamphlet into French, for his English, if he had any at all, would have been inadequate to the task. Probably he did not even instigate the translation, for when the French version, apparently the work of Rozier himself, did appear, not long after, it is Trudaine de Montigny who is credited with making it available to the French reader. ${ }^{41}$ Although we do not have Lavoisier's reply to Trudaine's letter, it is at least possible that he reminded Trudaine that Rozier was in a good position to have Priestley's work translated afresh or to have Magellan's summary corrected.

Lavoisier was already on familiar terms with Rozier, who in succeeding months was to play a central part in spreading abroad through the pages of his recently founded journal a knowledge of English pneumatic chemistry, giving generous space to abridgments and translations of the work of the British chemists and their Continental supporters and critics. For this important contribution Rozier deserves more attention than he has received.

A native of the Lyonnais who had won a modest reputation as an agronomist and man of science, François Rozier (1734-1793) was probably best known, before his arrival in Paris, for a prize-winning essay on the chemistry of winemaking. ${ }^{42}$ For a short time he had been director of

40 Procès-verbaux, 91 (1772), fol. 254 verso, where we read: "M. Lavoisier a lu une lettre de M. Magellens au sujet de L'air fixe." ${ }^{41}$ When, on August 14, Trudaine distributed at the Academy of Sciences copies of the translation of Priestley's brochure, it was described as translated "de L'Anglois de M. Joseph Priestley par M. L. Rozier” (Procès-verbaux, 91, fol. 286 verso).

${ }^{42}$ For Rozier, besides the articles in the Nouvelle biographie gé- 
the Ecole royale de médecine vétérinaire, established at Lyons in 1763 by the eminent Bourgelat. Deprived of his post after a dispute with the founder, Rozier retired to his father's estate near Lyons and for a time devoted himself to agricultural experiments, living on a small inheritance, which the cost of those experiments soon dissipated. About 1771, having been made Chevalier de l'Eglise de Lyon, a minor decoration which brought with it a modest competence, he moved to Paris and acquired the rights to a defunct scientific publication, the Observations sur l'histoire naturelle, sur la physique et sur la peinture, which had appeared, with variations of title but without notable success, between 1752 and 1758. Under Rozier's energetic editorship the first issue of a wholly reconstituted journal appeared in July, 1771, with the title Observations sur la physique, sur l'histoire naturelle et sur les arts. ${ }^{43}$

nérale and in Quérard, La France littéraire, the reader may consult A. J. Dugour, "Notice sur la vie et les écrits de l'Abbé Rozier," in Rozier's posthumous Cours complet d'agriculture . . . ou dictionnaire universel d'agriculture, X (An VIII-1800), pp. i-xvi; Alphonse de Boisseau, Eloge de l'Abbé Rozier (Lyon, 1832); and the sketch by M. Cochard (who had married Rozier's niece), Notice historique sur l'Abbé Rozier (Lyon, 1832). There are glimpses of Rozier later in his career in Arthur Young's Travels. See Henri Sée's excellently annotated translation, Voyages en France en 1787, 1788, et 1789, (Paris, 1931) I, 128-130 and 452-453.

Rozier compiled a valuable index to the serial publications of the Academy of Sciences from 1666 to 1770 . In his introduction he proposed a card file for compiling indexes and for similar purposes, using the blank side of ordinary playing cards. See his Nouvelle table des articles contenus dans les volumes de l'Académie Royale des Sciences de Paris, depuis 1666 jusqu'en 1770 (Paris, 17751776), I, pp. xi-xii. Just such a card index, using playing cards, is to be found with the Bordeaux MS of Rouelle's chemical lectures, a MS written after 1772-1773.

43 For Rozier's journal see, besides Douglas McKie's more recent 
Rozier's new publication filled a lamentable gap in the scientific periodical literature of France, which had been largely monopolized by the leisurely publications of the Academy of Sciences. The Observations, by contrast, offered prompt printing of scientific results, especially in rapidly growing fields like chemistry and experimental physics; it could provide a forum for those who were not privileged to use the sacrosanct pages of the Academy's Mémoires or the intermittent Savants étrangers; above all, the editor promised to report at length on foreign books and to print translations of foreign memoirs. Not only, as Rozier pointed out to his readers, had matters reached a point where the Academic publications were no longer adequate, but there was insufficient comprehension in France of the work of foreign investigators: "Il semble qu'à mesure que le nombre des Savans s'est accru, la Correspondance, entre ceux des Nations différentes, a été rallentie." ${ }^{44}$

By the summer of 1772 Rozier's journal had been appearing for only a year, but it had already won wide esteem and in large measure was fulfilling its founder's objectives. In the first issues Rozier included papers by obscure but earnest contributors from the French provinces, as well as

article in Annals of Science, cited above, his paper "The Scientific Periodical from 1665 to 1798," in Natural Philosophy through the Eighteenth Century and Allied Topics (a commemoration number of the Philosophical Magazine; London, 1948), pp. 127-130. Some interesting material is found in E. W. J. Neave's rather disappointing "Chemistry in Rozier's Journal," Annals of Science, 6 (1950), 416421; 7 (1951), 101-106, 284-299, 393-400; and 8 (1952), 28-45.

44 Cited from Rozier's "Avis" to the reader, in the first quarto number (January, 1773), by McKie, "The Scientific Periodical," loc. cit., pp. 127-129. 
translations of memoirs and communications by scientists of Germany, Sweden, Switzerland, Italy, and Great Britain. Members of the Academy of Sciences were slow to take advantage of this new medium of publication, with one significant exception. Lavoisier-young, energetic, ambitious, and impatient to see his results printed as rapidly as possible-was the first academician to make extensive use of the facilities Rozier offered. In the second number (August, 1771) there appeared a summary of Lavoisier's classic experiments on the presumed transmutation of water into earth, which the young chemist had read to the Academy the previous November. ${ }^{45}$ In the issue for May, 1772, Rozier printed Lavoisier's anonymous report on

45 Introduction aux observations, I, 78-83. This purports to be an account, prepared from memory, of Lavoisier's presentation at the séance publique of the Academy on November 14, 1770. But Meldrum-the first to realize the importance of Rozier's journal in establishing the chronological development of Lavoisier's early work - was convinced that this summary, or material for it, had been supplied by Lavoisier himself. See Meldrum, "Lavoisier's Early Work in Science," loc. cit., 20, 405-409; cf. Duveen and Klickstein, op. cit., pp. 19-21.

Lavoisier's work on water had been referred to earlier in the issue of July, 1771, in an editor's footnote to the dissertation by a Swedish scientist on whether the waters of the ocean progressively diminish. See Introduction aux observations, I, 7. McKie has recently found in the duodecimo edition an announcement concerning the plan for the mineralogical atlas, in the course of which Rozier wrote that “Messieurs Guettard, Lavoisier \& plusieurs Sçavans n'épargnent ni soins, ni tems, ni voyages pour perfectionner cet Atlas minéralogique." Because this notice appeared under "Nouvelles littéraires," it was not reprinted in the Introduction aux observations of 1777 . See McKie, "The 'Observations' of the Abbé François Rozier," loc. cit., pp. 84-85. This would seem to provide additional evidence for an early and close connection between the Abbé Rozier and Lavoisier. 
the experiments he had conducted with Macquer and Cadet on the destruction of the diamond. ${ }^{46}$ In June of 1772 Lavoisier published an indignant letter to the editor concerning the "jeune homme prétendu Hydroscope," a dowser who claimed to be able to locate subterranean waters. ${ }^{47}$ In July the journal carried an Academy report on the Abbé Bachelay's meteorite, signed by Fougeroux, Cadet, and Lavoisier; accompanying it in the same issue was Lavoisier's first printed contribution to meteorology, his "Observations sur un effet singulier du Tonnerre." 48

There has naturally been a temptation to see Lavoisier's hand in Rozier's program-begun with the publication of a French version of Priestley's Directions-of disseminating the facts about British pneumatic chemistry during the course of 1772-1773. Yet I doubt if Lavoisier "took the initiative," as Meldrum suggests, in proposing the series of translations to Rozier. ${ }^{49}$ Trudaine and Magellan are as

46 Introduction aux observations, II, 108-111. See below, pp. 84-
86.

48 Ibid., II, 251-255 and 310-312. The issue of August, 1772, contained a letter of Lavoisier to the editor describing the project for a mineralogical atlas and asking for collaborators; this is accompanied by instructions for making useful observations (ibid., II, 372-376).

49 Meldrum has written: "I make the supposition that Lavoisier took the initiative in proposing these [translations and abridgments] to Rozier, who was the editor, and that Rozier concurred, willing to let matter of moment and controversy appear in his periodical. It is certain that Lavoisier took a far greater interest in gases than any other French chemist" (Eighteenth Century Revolution in Science, p. 28). This, of course, is only speculation. That contemporaries associated Lavoisier with these translations and abridgments is, however, suggested by the following passage written in 1774: “M. de Lavoisier, de notre Académie des sciences, vient de traduire et de rassembler en un volume in- $8^{\circ}$ tout ce qui a été écrit et s'est dit 
likely instigators, if, perhaps, we should not give the principal credit to Rozier himself; these men were already in close communication, and there is evidence that Rozier was already using material transmitted to him by Trudaine from Magellan. ${ }^{50}$ So close, indeed, was the relationship of Trudaine and Rozier, that the latter was in the habit, at least he was some years later, of receiving packages of books and other items by using Trudaine's address and franking privilege; ${ }^{51}$ this (as we have seen) was already

depuis deux ans sur la découverte de l'air fixe. Quoiqu'il n'y ait rien de lui dans ce recueil, la manière dont il a redigé les différents ouvrages qui ont paru en Angleterre sur ces objet mérite des éloges, et son travail a un grand succès. Ce sont principalement les Mémoires de M. Priestley, Anel [sic], Macbride, qu'il nous a transmis. On dit cet ouvrage très-curieux et très intéressant" (Correspondance littéraire, philosophique et critique par Grimm, Diderot, Raynal, Meister, etc., ed. Maurice Tourneux [Paris, 1879], X, 349). No such work by Lavoisier is known; indeed, this is certainly a woefully inaccurate reference, at second hand, to Lavoisier's Opuscules physiques et chimiques, which appeared in January, 1774. This, of course, included a long historical section making full use of the translations printed by Rozier; but original work by Lavoisier is very definitely included. The passage hardly deserves notice, except as it may reflect contemporary rumor that Lavoisier had something to do with the translations that had appeared; this evidence is far from weighty. ${ }^{50}$ The "Description du barometre de Ramsden," which Rozier printed in January, 1772 (Introduction aux observations, I, 509512 ), suggests to me a communication from Magellan.

${ }^{51}$ In a letter to the Academy of Bordeaux, dated September 14, 1776, Rozier writes: "Permettes que je vous prie, Monsieur, d'engager votre académie à me communiquer ses mémoires interressans ou couronnés. Vous pourres me les faire parvenir sans frais si vous aves la bonté de faire deux envéloppes. Sur l'intérieure cachetée avec du pain à cacheter, il ne faut Ecrire que ces seuls mots journal de physique et sur l'exterieure cachetée de la cire d'espagne mettre cette adresse-à $\mathrm{MM}$ de Trudaine intendant général des finances en son hotel à Paris" (Bibliothèque de Bordeaux, MS 828, XXI, no. 57). 
Magellan's established channel of communication. Moreover, we should not underestimate Rozier's own interest in the newly revealed world of British pneumatic chemistry, for chemistry-including the early pneumatic chemistry of Stephen Hales-was an area in which he had some competence as a scientist, as his work on vinification testifies. It need hardly be added that if Trudaine and Magellan had urged him to publish such a series of translations and abridgments on such an important and timely question, he would certainly have found the idea precisely in line with his editorial purpose.

Be that as it may, when Rozier published in August, 1772, his translation of Priestley's Directions-both in his journal and as a separate brochure-this proved the first effective step in arousing the curiosity of French chemists about this promising new field of investigation, ${ }^{52}$ the more so because Rozier, with a pardonable display of national pride, took the occasion to call attention to a neglected French work on the same subject.

As long ago as 1750 Gabriel François Venel, a pupil of

52 "Manière d'imprégner l'Eau d'air fixe, \& de lui communiquer les propriétés de l'Eau de Pyrmont, \& de toutes les Eaux minérales, qui sont connues sous le nom d'Acidules ou Aëriennes, par M. J. Priestley," Introduction aux observations, II, 323-331. A footnote reads: 'Le Public est averti que c'est au zèle de M. de Trudaine pour les Sciences, à la protection dont il veut bien les honorer, \& à l'attention vraiment philosophique qu'il donne à tout ce qui peut intéresser l'humanité, qu'il doit la traduction \& la publication de cet Ouvrage." Rozier's translation is quite adequate but omits Priestley's dedicatory epistle to the Earl of Sandwich and the author's preface. Notes by Rozier and one by Magellan are appended; the single plate that appeared in the original is given here redrawn and specially engraved. The catalogue of the Bibliothèque Nationale lists the separate printing (in- $8^{\circ}$, so not a mere separate) of this Priestley translation. It is evidently this which Trudaine distributed to members of the Academy on August 14. 
G. F. Rouelle and at that time director of the private laboratory of the Duc d'Orléans, ${ }^{53}$ had read two memoirs before the Academy of Sciences proving that the waters of Selters near Coblentz owed their piquancy and savor to air combined with or dissolved in the water..$^{54}$ By various methods-agitation, heating, and the use of the vacuum pump-he had extracted air from the mineral water, leaving it flat and tasteless; and he had prepared an unpleasantly saline imitation of Seltzer water by mixing soda and muriatic acid in a closed bottle of pure water. These experiments aroused little interest, ${ }^{55}$ and indeed by 1772

${ }^{53}$ Venel studied medicine at Montpellier and received the M.D. in 1742. Early in his studies he was attracted to chemistry, probably by the lectures of Sébastien Matte, demonstrator in chemistry at the university. As early as 1739 he had acquired a copy of a pioneering work on phlogistic chemistry, J. B. Senac's anonymous Nouveau cours de chymie suivant les principes de Newton \& de Sthall (2 vols.; Paris, 1723). Venel's inscribed and dated copy of this book is owned by my friend, Mr. W. A. Cole, of Pacific Palisades, California. A revised edition (2 vols.; Paris, 1737) is more common. Senac's authorship of this book, now generally accepted, is confirmed by a letter of Macquer to Torbern Bergman (dated February 22, 1768). This is to be printed in Johan Nordström's forthcoming Foreign Correspondence of Torbern Bergman.

The chief biographical source on Venel is E. H. de Ratte's "Eloge de Monsieur Venel," Observations sur la physique, 10 (1777), 3-14. An abridged version of this sketch was printed by Baron Des Genettes in Eloges des académiciens de Montpellier (Paris, 1811), pp. 194-203. There are further comments on Venel in the eulogy of Venel's collaborator, Jacques Montet, in the same volume, pp. 247-248.

${ }^{54}$ Mémoires de mathématiques et de physique présentés à l'Académie royale des sciences par divers sçavans, et lus dans ses assemblées, II (1755), 53-79 and 80-112. Stephen Hales is quoted by Venel on pp. 64 and 66 . This is the collection commonly referred to as the Mémoires des savants étrangers. See above p. 19.

55 Venel's work is mentioned in Diderot's Encyclopédie in the 


\section{PNEUMATIC CHEMISTRY}

Venel had ceased to do creative research and had faded from the scene. Rozier resurrected him by appending to the Priestley translation an "Extrait de deux Mémoires de M. Venel," adding the comment that they proved that the discovery of air in mineral waters "appartient à la Chymie Françoise," and that the same could be said of the "imitation des eaux aerées." To Priestley, he conceded, must go the credit for showing that an air produced by effervescence can be made to pass into water or other fluid by simple agitation, and to the English, notably MacBride, priority for discovering the medical value of "fixed air." These claims on Venel's behalf greatly annoyed Magellan, the admirer and friend of Priestley. ${ }^{56}$

article "Minerales, eaux; chym. \& med." (X [1765], 534-541), an abridgment of a Latin treatise by Charles Le Roy, Venel's younger colleague at Montpellier; also in Turgot's article "Expansibilité" (VI [1756], 274-285). Macquer briefly noticed Venel's work in his Dictionnaire de chymie of 1766 (I, 391). In the same year Demachy attacked Venel's findings, without mentioning him by name, in the paper discussed above. After he became professor of medicine at Montpellier in 1759, Venel published no chemical research, though he gave public lectures in chemistry in the laboratory of Jacques Montet (another Rouelle pupil and a fellow member of the Academy of Montpellier). Rozier in 1772 lamented "l'espèce d'inaction dans laquelle [Venel] semble être tombé" (Introduction aux observations, II, 332). However in 1774 , impelled by the critical shortage of firewood in the region of Montpellier, Venel wrote his Instruction sur l'usage de la houille (Avignon, 1775), a work advocating and explaining the use of coal. This was his last work, for he died on October 29, 1775. For appraisals of his contributions to chemistry see Gmelin, op. cit., II, passim; Hoefer, Histoire de la chimie (2nd ed.; Paris, 1866-1869), II, 342-343; and, on a special point, J. R. Partington and Douglas McKie, "Historical Studies on the Phlogiston Theory-I. The Levity of Phlogiston," Annals of Science, 2 (1937), 380-381.

${ }^{56}$ Magellan wrote to Lavoisier on February 11, 1774, to acknowl- 
It was several months before Rozier was able to bring out the next of his translations and abridgments concerned with pneumatic chemistry. But in August, 1772-at a time when, as we have seen, Lavoisier appears to have been unacquainted with the work of Joseph Black-Rozier was well launched on his project. In the September issue of his Observations he published the first significant fragment of Blackiana, a brief summary of some of the experiments on latent heat, entitled "Expériences du Docteur Black, sur la marche de la Chaleur dans certaines circonstances." 57 This summary, the earliest account of Black's work on heat to appear on the Continent and the second to appear anywhere, ${ }^{58}$ was described by Rozier as communicated from Edinburgh "par un des Disciples du Docteur Black.” Who this "disciple" may have been, we do not know, but his communication was probably transmitted by the path already so familiar to us, i.e., via Magellan and Trudaine. That this was the channel of transmission is rendered more than inherently probable by the fact that, in advance of

edge receipt of the Opuscules: "La note que vous avez faite sur la decouverte de $\mathbf{M}^{\mathbf{r}}$ Vennel [sic] m’a donné beaucoup de satisfaction. Car je m'avois presque brouillé avec l'Abbé Rozier de ne pas avoir fait justice dans le particulier, attribuant toute l'invention de l'air fixe à M. Venel, qui n'a jamais Connu d'autre air, dans les eaux acidules, que l'air Commun. . . . Le $\mathrm{D}^{\mathrm{r}}$ Hales avait trouvé bien La meme chose avant lui, et se trompe de meme" (Oeuvres de Lavoisier-Correspondance, II [1957], 430).

57 Introduction aux observations, II, 428-431.

${ }^{58}$ Black never published his own work on heat. The earliest account is to be found in an anonymous publication brought out by the printer and bookseller, John Nourse, in London in 1770 entitled An Enquiry into the General Effects of Heat; with Observations on the Theories of Mixtures. See McKie and Heathcote, Discovery of Specific and Latent Heats, pp. 50-51. 
publication, the substance of this abridgment was reported to the Academy of Sciences by Nicolas Desmarest, a close friend of Trudaine and his professional associate in the work of the Bureau de commerce. We shall discuss this episode in more detail in the next chapter, but from Rozier's prefatory remarks Lavoisier and his fellow chemists could learn, perhaps for the first time, of the importance of Black's chemical discoveries:

L'école d'Edimbourg fera époque dans l'Histoire de la Physique, pour s'être principalement occupée du feu \& de l'air fixe. Le Docteur Black est celui qui a le plus multiplié les expériences sur ces deux points importans. Nous nous proposons de les rapprocher \& d'en former un ensemble instructif, qui puisse donner à nos Compatriotes, une idée de tout le travail de cet Académicien. Comme les expériences suivantes ne roulent que sur un point isolé, nous avons cru devoir les détacher des autres, que nous présenterons le plutôt qu'il sera possible à nos Lecteurs curieux d'expériences, dont les résultats sont aussi piquans que les procédés en sont ingénieux. ${ }^{59}$

It is obvious that Rozier clearly understood the central importance of Black's work and either had in his possession Black's chemical masterpiece or was in the process of obtaining it to have a translation made. Yet it was not until February, 1773, that he was able to print a "précis raisonné" of the work of Nicolas Jacquin, Black's Viennese disciple, and to preface it with a brief but clear account of the discovery of "fixed air." The translation of Black's Experiments upon Magnesia Alba eventually appeared

59 Introduction aux observations, II, 428. The whole summary has been recently reprinted from the duodecimo Observations by McKie in Annals of Science, 13 (1957), 86-89. 
in the March and April issues of Rozier's journal. ${ }^{60}$ Thus in the fall of 1772 , apart from the earlier book of MacBride, only Priestley's little pamphlet on artificial soda water was available in translation to represent the work of Black and his disciples. Most, if not all, of the papers Rozier subsequently published probably came into his hands between August and December, 1772. But it is not easy to discover precisely when, and to what extent during these months, Lavoisier was able to consult these writings. That he was in touch with Rozier and aware of his activities is certain, ${ }^{61}$ and he was probably kept informed by Trudaine or Rozier himself of the information that Magellan was hastening to make available. In midAugust, for example, Lavoisier appears to have had advance notice of the contents of Desmarest's report on Black's latent heat experiments. ${ }^{62}$ And by the time he set down his famous memorandum of February 20, 1773, Lavoisier could write as if he had a considerable familiarity with the literature on "fixed air," including a knowledge of works Rozier had not yet printed. In this important document Lavoisier refers, in the precise order of their original publication, to the experiments of Hales, Black, MacBride, Jacquin, Crantz, Priestley, and De Smeth, the last named being the author of a thesis printed only in October, 1772. To be sure, we cannot be certain that Lavoisier had read and carefully assimilated all these

${ }^{60}$ Observations sur la physique, 1 (1773), 123-134, 210-220, and 261-275.

${ }^{61}$ Cf. my "Joseph Priestley's First Papers on Gases," loc. cit., pp. 7-8; but I am no longer convinced that Lavoisier "may have had a hand in these translations."

62 For this episode see below, pp. 92-94, and my "A Lost Memoir of Lavoisier," loc. cit., pp. 128-129. 
works, but that is the impression he conveys; for he speaks of them as the separate links of a great chain, which he hoped, by writing a history of previous developments and by carrying out a long series of experiments, to build into a new and revolutionary theory. The evidence, therefore, suggests that Lavoisier acquired most of his knowledge of the work done abroad on the chemistry of air, not before he carried out his famous experiments in the autumn of 1772 , but probably during or after these historic months. ${ }^{63}$

We must, therefore, exclude any direct influence of the writings of Black, Jacquin, and Cavendish (a name notably absent from the February memorandum) upon Lavoisier's first steps in the study of air and combustion. On the other hand, Priestley's first little publication on soda water, which aroused keen interest in the subject of "fixed air" and in the earlier book of MacBride, must have had an appreciable effect on Lavoisier, as we know it did on his contemporaries. At least three of Lavoisier's fellow chemists-J. B. M. Bucquet (1746-1780), Hilaire-Marin Rouelle (1718-1779), and Pierre Bayen (1725-1798)undertook experiments late in 1772 or early in 1773 which dealt directly with the production and properties of "fixed air," and the work of these men reflects the stimulus of Priestley's pamphlet and the discussions it aroused. Bucquet performed his experiments in the laboratory of the Duc de la Rochefoucauld d'Enville, using an improved version of MacBride's apparatus. These experiments, perhaps suggested to him by Lavoisier, convinced him that the air produced by the action of acids on chalk and mild alkalis was the same whatever acid was used; that it was

${ }^{63}$ This was also Meldrum's opinion. See his Eighteenth Century Revolution in Science, p. 12. 
identical with the air produced in fermentation; and that, though its density and compressibility seemed to differ little from those of atmospheric air, it was chemically distinct not only from common air, but also from the insoluble, inflammable air produced by the action of acids on metals. These results, which Bucquet obtained before he could learn of the work of Cavendish or had read Priestley's "Observations on Different Kinds of Air," were reported to the Academy of Sciences on April 24, 1773. The experiments may have been begun as early as the fall of $1772 .^{64}$

The younger Rouelle's experiments, published the following month (May, 1773) in Roux's Journal de médecine, seem also to have been inspired by Priestley's pamphlet, for they dealt with artificial chalybeate waters that could be produced by the action on various iron ores of water impregnated with "fixed air." ${ }^{65}$ It seems also to have been

${ }^{64}$ There is evidence to suggest that Lavoisier and Bucquet had begun some sort of collaboration as early as 1772 . If so, it is possible that Lavoisier suggested that his younger friend confirm and extend Priestley's findings, as Trudaine had urged. For Bucquet see Balteau, op. cit., VII (1956), 606-607. His memoir, entitled "Experiences physico-chimiques sur l'air qui se dégage des corps dans le temps de leur décomposition et qu'on connaît sous le nom vulgaire d'air fixé," does not seem to have been published. Yet Lavoisier, who with Desmarest was charged with reporting on it, later gave a short account of it in his Opuscules (Oeuvres de Lavoisier, I, 548-550). The report by Lavoisier and Desmarest, dated June 12, 1773, was found among Lavoisier's papers and published by the editor of the Oeuvres (IV, 155-158). Lavoisier's laboratory registres show that in the second week of May, 1773, he began to repeat Bucquet's experiments, using Bucquet's improvement of MacBride's apparatus. See Berthelot, Révolution chimique, pp. $239 \mathrm{f}$.

${ }^{65}$ Lavoisier reproduced Rouelle's paper in his Opuscules (Oeuvres de Lavoisier, I, 538-547). On April 30, 1773-the day 


\section{PNEUMATIC CHEMISTRY}

during the same period, 1772-1773, that Bayen obtained "fixed air" by strongly heating samples of spathic iron ore (siderite). ${ }^{66}$

It is important to emphasize that all of these investigations were undertaken at about the time that Lavoisier was turning his attention to the possible role of air in combustion, yet before he undertook to explore directly, as these other men were doing, the properties of Black's "fixed air."

That Lavoisier, too, was in some degree influenced by Priestley's pamphlet is quite likely; it was he, as we have seen, who first described this work to the Academy. A few months later he included Priestley in his list of pneumatic chemists in the February memorandum; and this mention of Priestley, as I have shown elsewhere, could only have been for the Directions and not, as has usually been thought, for his classic paper, "Observations on Different Kinds of Air," which was not known in Paris until the spring of 1773. Lavoisier apparently did not follow Trudaine's suggestion that he repeat Priestley's experiments; at least there is no evidence that he did; and unlike some of his fellow chemists, he did not turn at once to a

that Lavoisier began his reading of what was to become the historical part of the Opuscules-the Comte de Milly (1728-1784) read to the Academy a memoir entitled "L'examen de quelques phénomènes attribués à l'air fixe" (Procès-verbaux, 92 [1773], fol. 103).

${ }^{68}$ Opuscules chimiques de Pierre Bayen, II, 1-40. Bayen read this paper before the Academy of Sciences on June 25, 1774; the experiments, which he had quoted in a memoir on mercury precipitates published in April, 1774, had been carried out earlier "c'est à dire, à l'époque oû la question de l'air fixe commençoit à occuper tous les chimistes." 
study of the properties of "fixed air." Perhaps, as I have suggested, he urged Bucquet to undertake this task. But the memorandum of August 8, 1772, and the newly discovered memoir on the elements he drafted at about the same time, which I shall discuss in the next chapter, make it clear that he had begun to speculate about "effervescences" and the role that air might play in chemical processes. Perhaps this curiosity about effervescences was in part aroused, and certainly it must have been quickened, by reading Priestley's pamphlet, which had come into his hands in mid-July. But it is more likely that he had already been led to his fruitful hypothesis somewhat earlier by a consideration of Hales's experiments, in connection with a specific problem I shall discuss below. If this is true, the appearance of Priestley's pamphlet, the discussions and experimentation it evoked, together with the growing realization that other and still more significant work had been done in Britain, would merely have convinced him that he was on the right track and that there was no time to lose.

At all events, the evidence is clear that Lavoisier recorded his first interest in the possible role of air in chemical change and embarked on his study of combustion at precisely the time when-through the activities of Magellan, Trudaine, and Rozier-the attention of French chemists was being drawn to the significance of British pneumatic chemistry, yet before they could have known at first hand the important contributions of Joseph Black and Henry Cavendish, and before they could have heard more than vague reports of the epoch-making results Joseph Priestley was at that time readying for the press.

It could hardly have been Priestley, or any other British chemist, whom Lavoisier was to conjure up as a rival 
when, to assure himself priority, he set down his brilliant discoveries of the autumn of $\mathbf{1 7 7 2}$ in the sealed note of November 1. Yet this is what Lavoisier wanted posterity to believe. Years later, when preparing this famous note for publication, he altered-without regard to the Muse of History-the words of its final paragraph. ${ }^{67}$ The original document makes it abundantly clear, in the words Lavoisier hurriedly set down at the time, that it was not the British but the French chemists who seemed to be pressing hard upon him and to whom he feared he might inadvertently disclose, before the proper time, something of his discoveries and his theories. In the version that all Lavoisier scholars have been accustomed to quote, he merely states that the novelty of his results had dictated this accepted procedure for protecting his property. ${ }^{68}$ But what he actually wrote in the autumn of 1772 was more clumsily phrased and more explicit:

Cette découverte me paroit une des plus interessantes qui ait ete faite depuis Sthal et Comme il est difficile de ne pas laisser entrevoir a Ses amis dans la Conversation quelque chose qui puisse les mettre Sur la voye de la verité jay Cru devoir faire le present depost entre les mains de M. le Secretaire de lacademie en attendant que je rende mes experiences publiques. ${ }^{69}$

${ }^{67}$ The reasons for Lavoisier's action are discussed in my forthcoming paper, "A Curious Lavoisier Episode," Chymia, in press.

${ }^{68}$ First printed in Lavoisier's posthumous Mémoires de chimie (1805), where it appears in a paper dealing with the history of the weight effect in calcined metals, this altered version was reproduced in the Oeuvres de Lavoisier (II, 103). It has since been unquestioningly reproduced by Meldrum, McKie, and other Lavoisier scholars.

${ }^{69}$ The original version, which survives in the archives of the Academy of Sciences, was first printed in 1957 by M. René Fric in Oeuvres de Lavoisier-Correspondance, II, 389-390. M. Fric did not note the discrepancies between the original and the commonly printed version. 